\title{
Correction to: Nitrogen Tax and Set-Aside as Greenhouse Gas Abatement Policies Under Global Change Scenarios: A Case Study for Germany
}

\author{
Martin Henseler $^{1,2,3} \cdot$ Ruth Delzeit ${ }^{4} \cdot$ Marcel Adenäuer $^{5} \cdot$ Sarah Baum ${ }^{1} \cdot$ Peter Kreins $^{1}$
}

Published online: 4 June 2021

(c) The Author(s) 2021

\section{Correction to: Environmental and Resource Economics (2020) 76:299-329 https://doi.org/10.1007/s10640-020-00425-0}

The article Nitrogen Tax and Set-Aside as Greenhouse Gas Abatement Policies Under Global Change Scenarios: A Case Study for Germany, written by Henseler, M., Delzeit, R., Adenäuer, M. et al., was originally published without Open Access. After publication in volume 76, issue 2-3, page 299-329 the author decided to opt for Open Choice and to make the article an Open Access publication. Therefore, the copyright of the article has been changed to (C) The Author(s) 2021 and the article is forthwith distributed under the terms of the Creative Commons Attribution 4.0 International License, which permits use, sharing, adaptation, distribution and reproduction in any medium or format, as long as you give appropriate credit to the original author(s) and the source, provide a link to the Creative Commons licence, and indicate if changes were made. The images or other third party material in this article are included in the article's Creative Commons licence, unless indicated otherwise in a credit line to the material. If material is not included in the article's Creative Commons licence and your intended use is not permitted by statutory regulation or exceeds the permitted use, you will need to obtain permission directly from the copyright holder. To view a copy of this licence, visit http://creativecommons.org/licen ses/by/4.0.

Publisher's Note Springer Nature remains neutral with regard to jurisdictional claims in published maps and institutional affiliations.

The original article can be found online at https://doi.org/10.1007/s10640-020-00425-0.

Martin Henseler

Martin.henseler@thuenen.de

Thünen Institute of Rural Studies, Bundesallee 64, 38116 Brunswick, Germany

2 Partnership for Economic Policy (PEP), Nairobi, Kenya

3 EDEHN - Equipe d'Economie Le Havre Normandie, Université du Havre, Le Havre, France

4 Kiel Institute for the World Economy, Kiel, Germany

5 OECD, Paris, France 